\title{
MODEL PENGEMBANGAN MEDIA PEMBELAJARAN PPKn BERBASIS ANDROID DI SMPN 25 MALANG
}

\author{
Naufal Muhammad Kautsar, Nurul Zuriah, Rohmad Widodo \\ FKIP Universitas Muhammadiyah Malang, Indonesia \\ Email: naufalmk@yahoo.com
}

\begin{abstract}
ABSTRAK
Penelitian ini bertujuan untuk: (1) Mengetahui kondisi kegiatan belajar dan mengajar PPKn sebelum adanya penerapan pengembangan media pembelajaran berbasis android. (2).Mengetahui pengembangan media pembelajaran berbasis IT yang ada di SMPN 25 Malang. Jenis penelitian yang digunakan dalam penelitian ini adalah jenis penelitian research and development. Sumber data dipilih kepala sekolah, guru kelas VIII, serta peserta didik kelas 8 di SMP Negeri 25 Malang. Penelitian ini dilaksanakan kurang lebih memerlukan waktu 6 bulan. Penelitian pengembangan ini menghasilkan produk akhir media pembelajaran berbasis aplikasi android yang disebut dengan media BENEKO Educapp. Pengembangan media dikembangkan melalui lima tahapan (analisis, design, development, implementation and evaluation). Berdasarkan hasil uji coba lapangan yang dilakukan pada kelas kecil dan besar. Uji coba kelas kecil dilakukan pada kelas VIII B dengan sampel random sebanyak 5 peserta didik, memperoleh hasil 82.6\% , disimpulan produk ini layak digunakan.Hasil uji coba luas dilakukan kepada kelas A, B, D. Hasil yang diperoleh 29 peserta didik kelas VIII A SMPN 25 Malang memperoleh respon dengan presentase 78,2\% , disimpulkan produk ini layak untuk digunakan. Uji coba luas dilakukan kepada 28 peserta didik kelas VIII C SMPN 25 Malang memperoleh respon dengan presentase $74.7 \%$, disimpulkan produk ini cukup layak untuk digunakan. Uji coba luas dilakukan kepada 29 peserta didik kelas VIII D SMPN 25 Malang memperoleh respon dengan presentase 87, 6 $\%$, disimpulkan produk ini sangat layak untuk digunakan.Terakhir uji coba lapangan dilakukan kepada guru PPKn kelas VIII SMPN 25 Malang memperoleh respon dengan skor 92, 7 \%, disimpulkan produk ini sangat layak untuk digunakan.
\end{abstract}

Kata Kunci: Android, BENEKO Educapp, Media, PPKn.

\begin{abstract}
This study aims to: (1) Know the condition of teaching and learning activities of PPKn before the implementation of the development of android-based learning media. (2). Knowing the development of IT-based learning media in SMPN 25 Malang. The type of research used in this study is the type of research and development research. As a data source selected principals, teachers class VIII, and 8th graders in SMP Negeri 25 Malang. This study was conducted approximately 1-6 months. This development research produces the end product of instructional media based on android application called BENEKO Educapp media. Media development is developed through five stages (analysis, design, development, implementation and evaluation).Based on field trials conducted on small and large classes. For small classes done in class VIII B with random samples of 5 students, obtained $82.6 \%$ results, this product concluded feasible to use. For extensive testing conducted to class A, B, D. The results obtained by 29 students of grade VIII A SMPN 25 Malang get response with percentage of $78.2 \%$, it is concluded that this product is suitable for use. Extensive trials conducted to 28 students of grade VIII C SMPN 25 Malang get response with a percentage of $74.7 \%$, concluded this product is quite feasible to use. Extensive trials were conducted to 29 students of grade VIII D SMPN 25 Malang obtained response with $87 \%$ percentage, $6 \%$, concluded this product is very feasible to use. The
\end{abstract}


last field trial was done to the teacher of Vocational School VIII SMPN 25 Malang get response with score $92,7 \%$, concluded this product very feasible to be used.

Keywords: Android, BENEKO Educapp, Media, PPKn.

\section{PENDAHULUAN}

Perkembangan teknologi saat ini sudah sangat pesat dan canggih, anak muda sekarang khususnya peserta didik SMA dan SMP sudah jauh lebih menguasai teknologi dibanding generasi sebelumnya, anak-anak SMP dan SMA sekarang sudah mempunyai gadget canggih seperti handphone untuk menunjang kehidupan. Sebagai seorang pendidik tentu harus bisa mengimbangi anak muda zaman sekarang dalam hal melek teknologi, supaya tidak dianggap ketinggalan zaman dan diremehkan peserta didik.

PPKn (Civic Education) adalah pembelajaran yang menggugah rasa ingin tahu dan kepercayaan (trust) terhadap norma-norma sosial yang mengatur hubungan personal dalam masyarakat sebagaimana mengatur partisipasi politik (Alberta dalam Susiatik, 2013).

Mata pelajaran Pendidikan Pancasila dan Kewaraganegaraan hilang maknanya apabila peserta didik tidak menyukai mata pelajaran tersebut. Ketidaksukaan ini di sebabkan karena menurut peserta didik materi PPKn terlalu rumit sehingga banyak yang harus dihafalkan. Para peserta didik sudah terlanjur menganggap PPKn adalah mata pelajaran hafalan, bukan pemahaman. Selain faktor di atas, penyebab PKn tidak diminati adalah dari pembawa materi itu sendiri, yaitu guru mata pelajaran PPKn. Menerangkan materi terlalu cepat sampai terlalu lamban. Selain itu, penjelasan dari guru tidak membuat peserta didik semakin jelas atas materi yang disampaikan, malah menambah bingung peserta didik. Terkadang juga, guru tidak begitu menguasai materi, sehingga terkadang ketika guru sedang mengajar di dalam kelas peserta didik kebanyakan tidak memperhatikan dan malah asik sendiri dengan teman-temannya (Allica, 2015).

Berdasarkan hal tersebut, Penulis sebagai mahasiswa Pendidikan Pancasila Kewarganegaraan Fakultas Keguruan dan Ilmu Pendidikan Universitas Muhammadiyah Malang, yang merupakan calon guru Pendidikan Kewarganegaraan, melakukan inovasi suatu media pembelajaran yang menggunakan media aplikasi android untuk menarik perhatian peserta didik agar peserta didik lebih konsentrasi dalam mengikuti mata pelajaran PPKn.

Menyesuaikan dengan kemajuan teknologi, tentunya diperlukan sebuah media pembelajaran yang menyelaraskan dengan kemajuan zaman, yang mampu merangsang minat seluruh tatanan masyarakat terutama peserta didik. Media yang dikembangkan tentulah harus dapat mengikuti kebutuhan zaman sekarang serta dapat diakses. Sayangnya, pemanfaatan media pembelajaran di Indonesia masih sangatlah minim, bagi media berupa IT maupun non-IT. Dibuktikan dengan hasil survei berikut ini bahwa permasalahan yang sering dihadapi oleh guru adalah "Peningkatan kemampuan di bidang keahlian" (42\%), "Minimnya alat bantu mengajar di sekolah" (24\%), "Kurikulum” (15\%), "Kompetensi Pedagogik perlu diasah" (8\%), "Gaji” (5\%), "Pelatihan dan diklat hanya teoritis" (3\%) dan permasalahan-permasalahan yang lain yang dihadapi guru (3\%) (Mashoedah, 2015).

Tetapi seiring kemajuan IPTEK di Indonesia, permasalahan pemanfaatan 
media yang inovatif dan mudah diakses menemui titik terang. Penggunaan media pembelajaran berbasis android dinilai mampu menjadi salah satu solusi meningkatkan minat mengikuti mata pelajaran PPKn di SMPN 25 Malang. Pasalnya, menurut lembaga riset digital marketing Emarketer pada tahun 2018 jumlah pengguna aktif smartphone di Indonesia diperkirakan akan mencapai lebih dari 100 juta orang. Artinya, Indonesia akan menempati posisi tertinggi keempat pengguna android terbanyak di dunia setelah Cina, India, dan Amerika (Rahmayani. 2015). Potensi pemakaian android di Indonesia khususnya di lingkungan sekolah SMPN 25 Malang harus bisa dimanfaatkan dengan baik khususnya dalam bidang akademik, maka dari itu penulis membawa salah satu inovasi solusi upaya menjawab peluang pengembangan media pembelajaran android untuk bidang pendidikan.

\section{METODE}

Penelitian ini bertempat di SMPN 25 Malang. Peneliti memilih SMPN 25 Malang di karenakan di SMPN 25 Malang peneliti mengenal lingkungan dan seluk beluk problematika di dalamnya, di karenakan kebetulan SMPN 25 merupakan tempat peneliti magang. Menurut analisa penulis SMPN 25 Malang merupakan tempat strategis untuk diadakan penelitian.

Pengembangan produk aplikasi android BENEKO EducApp ini menggunakan jenis pengembangan metode ADDIE. Pengembangan ADDIE terdiri atas 5 fase yang saling terkait, yaitu Analyze, Design, Develop, Implement, dan Evaluate.

ADDIE merupakan model desain media pembelajaran yang berlandaskan pada pendekatan sistematik sebagai prosedural pendekatan sistem yang telah diwujudkan dalam banyak praktik metodologi untuk pengembangan teks, materi. Hasil akhir dari penelitian ini merupakan produk awal bagi fase pengembangan berikutnya.

Observasi dilakukan bertempat di SMPN 25 Malang kelas VIII untuk mendapatkan informasi terkait proses pembelajaran, karakteristik peserta didik dan analisis kebutuhan di sekolah. Observasi dilakukan sebelum di berikan produk. Observasi dilakukan dengan cara mengamati kegiatan peserta didik selama proses belajar mengajar dikelas kususnya saat pembelajaran PPKn, apakah dalam proses pembelajaran PPKn sudah menggunakan media pembelajaran atau belum. Peneliti juga mengobservasi karakteristik peserta didik saat proses pembelajaran.

Wawancara pada penelitian ini dilakukan dengan mewawancarai guru PPKn kelas VIII dan kepala sekolah SMPN 25 Malang. Wawancara dengan Guru PPKn dilakukan untuk mendapatkan informasi ketika melakukan studi pendahuluan yang meliputi kendala guru dalam mengajar, mengetahui KI, KD dan materi yang digunakan dalam pembelajaran PPKn, mengetahui minat peserta didik terhadap mata pelajaran PPKn dan juga media pembelajaran yang digunakan dalam proses pembelajaran PPKn. Peneliti juga mewawancarai tentang kelemahan dan kelebihan media yang selama ini digunakan dalam proses pembelajaran. Sedangkan wawancara dengan kepala sekolah dilakukan untuk mendapatkan informasi mengenai pengembangan media pembelajaran berbasis IT yang telah dilakukan di SMPN 25 Malang. 
Angket pada penelitian berupa angket validasi, angket respon peserta didik, serta respon guru. Angket validasi diajukan kepada ahli media pembelajaran, ahli Pemprograman dan ahli materi (guru), angket respon peserta didik diberikan kepada peserta didik untuk mengetahui kemenarikan media pembelajaran yang akan dikembangkan. Terakhir angket respon guru diajukan kepada guru mata pelajaran PPKn kelas VIII. Angket validasi diberikan pada saat evaluasi produk untuk penyempurnaan produk media pembelajaran berbasis android. Angket respon peserta didik dan respon guru diberikan setelah produk diterapkan.

Peneliti menggunakan metode Annas dalam teknik analisis data. Annas (2016:55) menyebutkan "data yang berupa data verbal deskriptif dianalisis secara kualitatif. Sedangkan untuk menganalisis data berupa uji ahli, uji praktisi dan uji lapangan dilakukan secara kuantitatif”.

\section{HASIL DAN PEMBAHASAN}

\section{Kondisi proses kegiatan belajar dan mengajar PPKn}

Kondisi kegiatan belajar dan mengajar PPKn sebelum adanya penerapan dari pengembangan media pembelajaran berbasis android di kelas 8 SMPN 25 Malang, peserta didik ketika mata pelajaran PPKn jam mengajar Ibu Rhegita pagi, semangat belajarnya masih tinggi, tapi ketika Ibu Rhegita mengajar mata pelajaran PPKn siang, minat belajar peserta didik turun. Ketika mata pelajaran PPKn ditaruh pada saat jam pelajaran siang peserta didik kebanyakan mengantuk, tidak konsentrasi serta kurang semangat.

Media pembelajaran yang biasanya digunakan guru PPKn di kelas 8 SMPN 25 Malang adalah dengan media pembelajaran menggunakan kompas, dalam penggunaannya anak-anak nantinya akan melihat arah mata angin yang guru mata pelajaran tempel di power point, arah mata angin ada 4 yang menggunakan penamaan arah mata angin jawa. Di setiap arah mata angin itu ada akronimnya yaitu tahapan-tahapan yang harus anak-anak lakukan.

Tapi sayangnya, penggunaan media pembelajaran ini tidak begitu efektif dalam meningkatkan semangat peserta didik dalam proses pembelajaran.

Perkembangan dari suatu media pembelajaran berbasis IT di SMPN 25 sudah pernah dilakukan, namun kurang begitu optimal di karenakan ada peserta didik yang menyalahgunakan fasilitas IT untuk kegiatan negatif, sehingga sekolah akhirnya belum bisa memfasilitasi untuk adanya suatu pengembangan media berbasis IT kalau menggunakan HP android, karena rawan untuk disalahgunakan.

\section{Pengembangan Apliakasi Android Media Pebelajaran PPKn BENEKO Educapp. \\ Pengembangan produk aplikasi media pembelajaran BENEKO EducApp ini menggunakan jenis pengembangan metode} ADDIE. Pengembangan ADDIE terdiri atas 5 fase yang saling terkait, yaitu Analyze, Design, Development, Implement, dan Evaluate (Tegeh, dkk, 2014).

1. Tahap Validasi

Tahap ini media divalidasi oleh 1 orang ahli materi sekaligus user yaitu guru mata pelajaran PPKn, Ibu Regita Resih Kemuning, S.Pd dan 2 orang ahli IT yaitu operator jaringan Infokom UMM Bapak Faizal harwin. S.Kom, dan operator jaringan DPPM Dikky Cahyo Hariyanto. S.Kom. Terakhir ahli media pembelajaran Dr. Nurul Zuriah, M.Si. Masukan dan saran dari ahli materi, ahli media serta ahli 
IT akan dijadikan dasar untuk revisi media agar media yang dikembangkan menjadi lebih baik lagi.

Hasil yang diperoleh dari validasi media pembelajaran ahli materi berdasarkan angket validator dapat diperoleh skor 87,27 \%. Berdasarkan pedoman kelayakan kriteria interpretasi maka produk aplikasi BENEKO, berada pada kualifikasi "sangat layak" dengan mempunyai skor antara 86\%-100 \%, artinya produk aplikasi android ini dianggap sangat layak untuk dipakai di sekolah.

Hasil yang diperoleh dari validasi media pembelajaran ahli Program I berdasarkan angket validator dapat diperoleh skor 70 \%. Berdasarkan pedoman kelayakan kriteria interpretasi Sugiono, maka produk aplikasi android ini, berada pada kualifikasi “cukup layak” dengan mempunyai skor antara 56 \%-75 $\%$, artinya produk aplikasi android ini dianggap cukup layak untuk dipakai di sekolah.

Hasil yang diperoleh dari validasi media pembelajaran ahli Program II berdasarkan angket validator dapat diperoleh skor 90 \%. Berdasarkan pedoman kelayakan kriteria interpretasi Sugiono, maka produk aplikasi android ini, berada pada kualifikasi "sangat layak" dengan mempunyai skor antara 86\%-100 $\%$, artinya produk aplikasi android ini dianggap sangat layak untuk dipakai di sekolah meskipun perlu diperbaiki.

Hasil yang diperoleh dari validasi media pembelajaran ahli media pembelajaran berdasarkan angket validator dapat diperoleh skor 92,5\%. Berdasarkan pedoman kelayakan kriteria interpretasi Sugiono, maka produk aplikasi android ini, berada pada kualifikasi "sangat layak" dengan mempunyai skor antara 86\%-100 $\%$, artinya produk aplikasi android ini dianggap sangat layak untuk dipakai di sekolah.

\section{Tahap Implementasi}

Uji coba media dilakukan untuk mengetahui keterterapan media berbasis android. Peneliti memerlukan partisipasi peserta didik dalam melakukan uji coba media. Sehingga peneliti melakukan uji coba media pada sekolah SMPN 25 Malang kelas VIII dengan jumlah sampel 5 peserta didik untuk kelas VIII B untuk uji coba kecil dan uji kelompok besar di kelas VIII A, C, D jumlah sampel 29, 28, dan 29 peserta didik.

\section{a. Uji Coba Terbatas}

Hasil yang diperoleh dari data yang diperoleh dari uji coba produk kepada 5 peserta didik kelas VIII B SMP Negeri 25 Malang berdasarkan angket respon peserta didik dapat diperoleh skor $82.6 \%$. Berdasarkan pedoman kelayakan kriteria interpretasi sugiono, maka produk aplikasi android ini, berada pada kualifikasi "layak" dengan mempunyai skor antara $76 \%$ - 85 $\%$, artinya produk aplikasi android ini dianggap layak untuk dipakai di sekolah dan digunakan dalam media pembelajaran PPKn dan secara umum media pembelajaran Beneko Educapp ini tidak diperlukan adanya direvisi lagi.

b. Uji Coba Luas

Hasil yang diperoleh dari data yang diperoleh dari uji coba produk kepada 29 peserta didik kelas VIII A SMP Negeri 25 Malang berdasarkan angket respon peserta didik dapat diperoleh skor 78,2\%. Berdasarkan pedoman kelayakan kriteria interpretasi Sugiono, maka produk aplikasi android ini, berada pada kualifikasi "layak" dengan mempunyai skor antara $76 \%$ - 85 $\%$, artinya produk aplikasi android ini dianggap layak untuk dipakai di sekolah.

Hasil yang diperoleh dari data yang diperoleh dari uji coba produk kepada 28 
peserta didik kelas VIII C SMP Negeri 25 Malang berdasarkan angket respon peserta didik dapat diperoleh skor 74,7\%. Berdasarkan pedoman kelayakan kriteria interpretasi Sugiono, maka produk aplikasi android ini, berada pada kualifikasi “cukup layak” dengan mempunyai skor antara 56\%-75 \%, artinya produk aplikasi android ini dianggap cukup layak untuk dipakai di sekolah dan digunakan dalam media pembelajaran PPKn.

Hasil yang diperoleh dari data yang diperoleh dari uji coba produk kepada 29 peserta didik kelas VIII D SMP Negeri 25 Malang berdasarkan angket respon peserta didik dapat diperoleh skor 87, 6 \%. Berdasarkan pedoman kelayakan kriteria interpretasi Sugiono, maka produk aplikasi android ini, berada pada kualifikasi "sangat layak" dengan mempunyai skor antara 86\%-100 \%, artinya produk aplikasi android ini dianggap sangat layak untuk dipakai di sekolah dan digunakan dalam media pembelajaran PPKn.

\section{c. Hasil Respon Guru}

Penelitian ini respon guru digunakan peneliti untuk mengetahui kelayakan materi media pembelajaran yang dikembangkan dalam proses pembelajaran. Untuk mengetahui hasil respon guru, digunakan angket respon guru yang dilakukan oleh Ibu Rhegita Resih Kemuning, S.Pd selaku guru mata pelajaran PPKn kelas VIII SMPN 25 Malang. Peneliti memilih guru kelas sebagai respon guru karena guru kelas yang mengetahui karakteristik dan kebiasaan saat pembelajaran, sehingga guru tahu betul pengaruh sebelum penggunaan media dan sesudah penggunaan media itu seperti apa.

Hasil yang diperoleh dari responden guru PPKn kelas VIII SMPN 25 Malang berdasarkan angket dapat diperoleh skor
92,7 \%. Berdasarkan pedoman kelayakan kriteria interpretasi Sugiono , maka produk aplikasi android ini, berada pada kualifikasi "sangat layak" dengan mempunyai skor antara 86\%-100 \%, artinya produk aplikasi android ini dianggap sangat layak untuk dipakai di sekolah dan digunakan sebagai media pembelajaran PPKn.

4. Tahap Evaluasi

Bersamaan dengan uji coba aplikasi, penulis juga menyebar angket untuk melihat daya tarik dan kekurangan pada media. Dari segi inovasi dan ketertarikan, sebagian besar peserta didik termasuk guru pengampu menilai bahwa media ini inovatif dan sangat menarik. Tetapi, dari angket ditemukan kekurangan dan masukan mulai dari tombol close yang tidak berfungsi serta kompatibilitas media pada handphone peserta. Dari kritik dan masukan tersebut, maka penulis mengembangkan ulang media untuk mengatasi permasalahan yang muncul tadi. Di karenakan model ADDIE ini bersifat saling terkait, maka evaluasi dapat dilakukan pada tahap manapun sehingga yang mengambil peran penting dalam pengembangan aplikasi ini adalah pada tahap evaluasi.

Tabel Kriteria interpretasi sugiono dalam annas (2016 : 56)

\begin{tabular}{cll}
\hline Kategori & Persentase & Kualifikasi \\
\hline 4 & $86 \%-100 \%$ & Sangat Layak \\
3 & $76 \%-85 \%$ & Layak \\
2 & $56 \%-75 \%$ & Cukup Layak \\
1 & $<55 \%$ & Tidak Layak \\
\hline
\end{tabular}

\section{SIMPULAN}

Penelitian pengembangan ini menghasilkan produk akhir media pembelajaran berbasis aplikasi android yang disebut dengan media BENEKO Educapp. 
Pengembangan media dikembangkan melalui lima tahapan (analisis, design, development, implementation and evaluation). Tahap analisis digunakan untuk menganalisis permasalahan berdasarkan hasil observasi dan wawancara di sekolah. Tahap perancangan digunakan untuk penyusunan rancangan bentuk media yang akan dikembangkan. Tahap pengembangan adalah tahap untuk membuat dan merancang media untuk dilakukan uji validasi oleh para ahli. Kelayakan media pembelajaran BENEKO Educapp diperoleh dari hasil penilaian dan tanggapan positif dari uji validasi ahli, respon peserta didik dan respon guru. Hasil validasi ahli materi menunjukkan bahwa materi yang digunakan dalam media sudah sesuai dengan kompetensi yang berlaku hal ini sesuai dengan perolehan sebesar $87,27 \%$, hasil validasi ahli program I sebesar $70 \%$, hasil validasi ahli program II sebesar $90 \%$ serta hasil validasi ahli media pembelajaran 92,5\%. Skor tersebut menunjukkan bahwa media valid digunakan sebagai media pembelajaran.

Hasil uji coba kecil memperoleh hasil 82.6\% yang artinya produk ini layak digunakan. Hasil yang diperoleh dari uji coba luas 29 peserta didik kelas VIII A SMPN 25 Malang memperoleh respon yang baik dengan presentase $78,2 \%$ yang artinya produk ini layak untuk digunakan. Uji coba luas yang dilakukan kepada 28 peserta didik kelas VIII C SMPN 25 Malang memperoleh respon yang baik dengan presentase $74.7 \%$ yang artinya produk ini cukup layak untuk digunakan. Uji coba luas yang dilakukan kepada 29 peserta didik kelas VIII D SMPN 25 Malang memperoleh respon yang baik dengan presentase 87, $6 \%$ yang artinya produk ini sangat layak untuk digunakan.
Terakhir uji coba lapangan dilakukan kepada guru PPKn kelas VIII SMPN 25 Malang memperoleh respon yang baik dengan skor 92, 7 \% yang artinya produk ini sangat layak untuk digunakan. Pada beberapa data di atas dapat disimpulkan bahwa media BENEKO EDUCAPP dinyatakan layak.

\section{DAFTAR PUSTAKA}

Iis Prasetyo, "Teknik Analisis Data Dalam Research And Development", (Online), (http://staffnew.uny.ac.id/upload/132310875/pengabdian/teknikanalisis-data-dalam-research-anddevelopment.pdf.) Diakses 13 Desember 2017.

Ramhmayani, I. 2015. Indonesia Raksasa Teknologi Asia, (Online), https:// kominfo.go.id/content/detail/6095/ indonesia-raksasa-teknologi-digitalasia/0/sorotan_media. (diakses tanggal 26 Februari 2018).

Thrasning Ayu, Allica.2015. PKn Membosankan? Whats Wrong, (Online),https://www.kompasiana.com/ allica/pkn-membosankan-whatswrong_552fd0506ea83451408b465e. (Diakses 5 April 2018).

Tegeh, IM, et.al. 2014. Model Penelitian Pengembangan. Singaraja: Graha Ilmu.

Ribab Sibilana. Annas. Pengembangan Media Pembelajaran Berbasis Android Mata Pelajaran Pendidikan Agama Islam untuk Kelas XI di SMA Negeri 2 Malang. Tesis tidak Diterbitkan. Malang: Program Studi Magister Pendidikan Agama Islam Pascasarjana UIN Maulana Malik Ibrahim Malang. 
Susiatik, Titik. 2013. Pengembangan EModule Berbasis Problem Based Learning Mata Pelajaran Kimia Untuk Siswa Kelas X Sma Negeri 8 Malang, (Online), Vol 1 (6) : 1159-1168, (http://journal.um.ac.id/index.php/ jptpp/article/download/6460/2741) diakses 14 Mei 2018.

Mashoedah. 2015. Kajian Penggunaan Media Pembelajaran dalam Pelatihan Peningkatan Kompetensi Profesional Guru, (Online), Vol 1 (1) : 17 - 25, (https://journal.uny.ac.id/index.php/ elinvo/article/download/10875/8985) diakses 14 Desember 2017. 